\title{
Polymorphism and variation in modular animals: morphometric and density analyses of bryozoan avicularia
}

\author{
Michelle C. Carter ${ }^{1,2,3 *}$, Dennis P. Gordon ${ }^{2}$, Jonathan P.A. Gardner ${ }^{1}$ \\ ${ }^{1}$ Centre for Marine Environmental and Economic Research, School of Biological Sciences, Victoria University of Wellington, \\ PO Box 600, Wellington 6140, New Zealand \\ ${ }^{2}$ National Institute of Water \& Atmospheric Research (NIWA), Private Bag 14901, Kilbirnie, Wellington, New Zealand \\ ${ }^{3}$ Present address: 280 Braddon Road, Loughborough, Leicestershire LE11 5YX, UK
}

\begin{abstract}
Avicularia are polymorphic zooids characteristic of most species of cheilostome bryozoans. We examined the morphological diversity of avicularia to elucidate morphometric patterns in 38 cheilostome species from 11 superfamilies collected from a range of depths (habitats) around New Zealand. Multivariate statistical analyses of 4 types of avicularia (adventitious, interzooidal, vicarious and vibracula) showed that vicarious and vibracula were morphometrically invariable, and vibracula morphometrically distinct, even though these 4 types are dissimilar in their relationships to progenitor zooids and colony budding pattern. Adventitious types showed extensive overlap in morphospace with interzooidal and vicarious types. No depth-related effect on either morphometric variation or colony density of avicularia was discerned over the depth ranges studied $(<8,20-300$, and $600-1000 \mathrm{~m}$ ). Inter-colony variability in avicularian density existed in some species, whilst the main contributor to morphometric grouping was the type of avicularia involved. Greatest avicularian density occurred in colonies of those species possessing 2 types of avicularia (e.g. Caberea spp. adventitious and vibracula). Adventitious avicularia were the most common type, were morphometrically diverse and occurred at higher densities within colonies than interzooidal and vicarious types. Such polymorphism, frequency and density of adventitious types in natural populations may represent an evolutionary shift towards maximisation of functional efficiency at a smaller spatial scale of the colony. By analysing polymorph variation we show how a modular development promotes flexibility in module production, arrangement and morphology.
\end{abstract}

KEY WORDS: Avicularia · Polymorphism · Morphometrics · Modularity · Bryozoa · Functional diversity $\cdot$ New Zealand

Resale or republication not permitted without written consent of the publisher

\section{INTRODUCTION}

Benthic communities harbour an array of colonial organisms, many capable of producing extensive biogenic structures through the iterative production of functional modules (e.g. coral polyps, bryozoan zooids). Diverse forms may be generated by assembling a limited range of modules in different ways (Hageman 2003, Sánchez \& Lasker 2003, Hughes 2005). Following larval metamorphosis, a strictly sedentary existence necessitates that environmental pressures are responded to by growth rather than migration or escape. One key to such a growth strategy is architectural flexibility which is achieved via the iterative production of functionally and morphologically specialised modules (Jackson 1979, Hughes \& Jackson 1990, Hageman 2003, Hughes 2005). A modular design can therefore promote flexibility in polymorph production and in the way resources are partitioned among units; the result is a hierarchically constructed colony where labour is divided between constituent modules (Schopf 1973, Hageman 2003). 
Zooidal polymorphism in cheilostome bryozoans consists of primary feeding zooids (which occur in all colonies), modified feeding and non-feeding zooids such as sexual dimorphs, and non-feeding heterozooids modified for attachment (stolons) and colony reinforcement (Ryland 1970, Silén 1977, Dick \& Mawatari 2005). Additionally, many cheilostomes produce zooids bearing defensive spines, the occurrence of which may be induced by the presence of a known predator (Harvell 1991, 1992). Avicularia are also thought to have a defensive function (Kaufmann 1968, Winston 1984, 1986). These are modified zooids that lack a functional feeding apparatus (gut and tentacle crown) and acquire nutrients through a colony-wide transport system (funicular system) (Hyman 1959, Banta 1973, Silén 1977, Winston 1984, McKinney \& Jackson 1989). Avicularia are morphologically diverse (Fig. 1A-H), but the basic design resembles an autozooid with a hypertrophied operculum (mandible). In its relaxed state, the mandible normally lies open, exposing a modified orifice which is partially sealed by a membrane (palate) (Winston 1984).

Avicularia are classified into 4 main types. Three of these are defined by their budding position in the colony: (1) vicarious avicularia occupy the position of an autozooid in the budding sequence and have a comparable size (Fig. 1D,E); (2) interzooidal avicularia, which are smaller than their progenitor zooid, are squeezed in between autozooids (Fig. 1G); (3) adventitious avicularia develop on the lateral, frontal, or basal walls of an autozooid (Fig. 1A-C, F-H), and; (4) vibracula, which are defined by their unique morphology and are considered specialised avicularia. They differ from standard avicularia by the rotational ability of their hair-like mandibles, or setae, as opposed to movement in one plane (Fig. 1F) (Ryland 1970, Schopf 1973, Cook \& Chimonides 1978, Cheetham \& Cook 1983, Winston 1984, McKinney \& Jackson 1989). Some colonies can possess more than one type of avicularium (Winston 1984).

The vibracula of certain free-living bryozoans inhabiting sandy sediments function principally to remove sand particles from the colony, to deter larval settlement, and to provide support and locomotion (Cook 1963, Cook \& Chimonides 1978, O'Dea et al. 2004). The roles of adventitious, interzooidal and vicarious types of avicularia are less well known. Based on limited observational evidence, some avic- ularia have the ability to grasp and hold a small invertebrate epibiont, or at least to react in response to tactile stimulation by rapid closure of the mandible. Such behaviour has led to a general acceptance that avicularia have a defensive function (Kaufmann 1968, 1971, Winston 1984, 1986, 1991). Additionally, the diverse array of mandible morphologies (cf. Fig. 1A,H) has led to the belief that several functional facets associated with colony defence and protection are involved (Silén 1977, Winston 1984), but this putative association between avicularian morphology and functional capacity has not been rigorously examined (but see Kaufmann 1968 for Bugula). The small size of avicularia, ranging from 50 to $1000 \mu \mathrm{m}$ (in very rare cases) in length (Carter 2008), makes experimentation very dif-
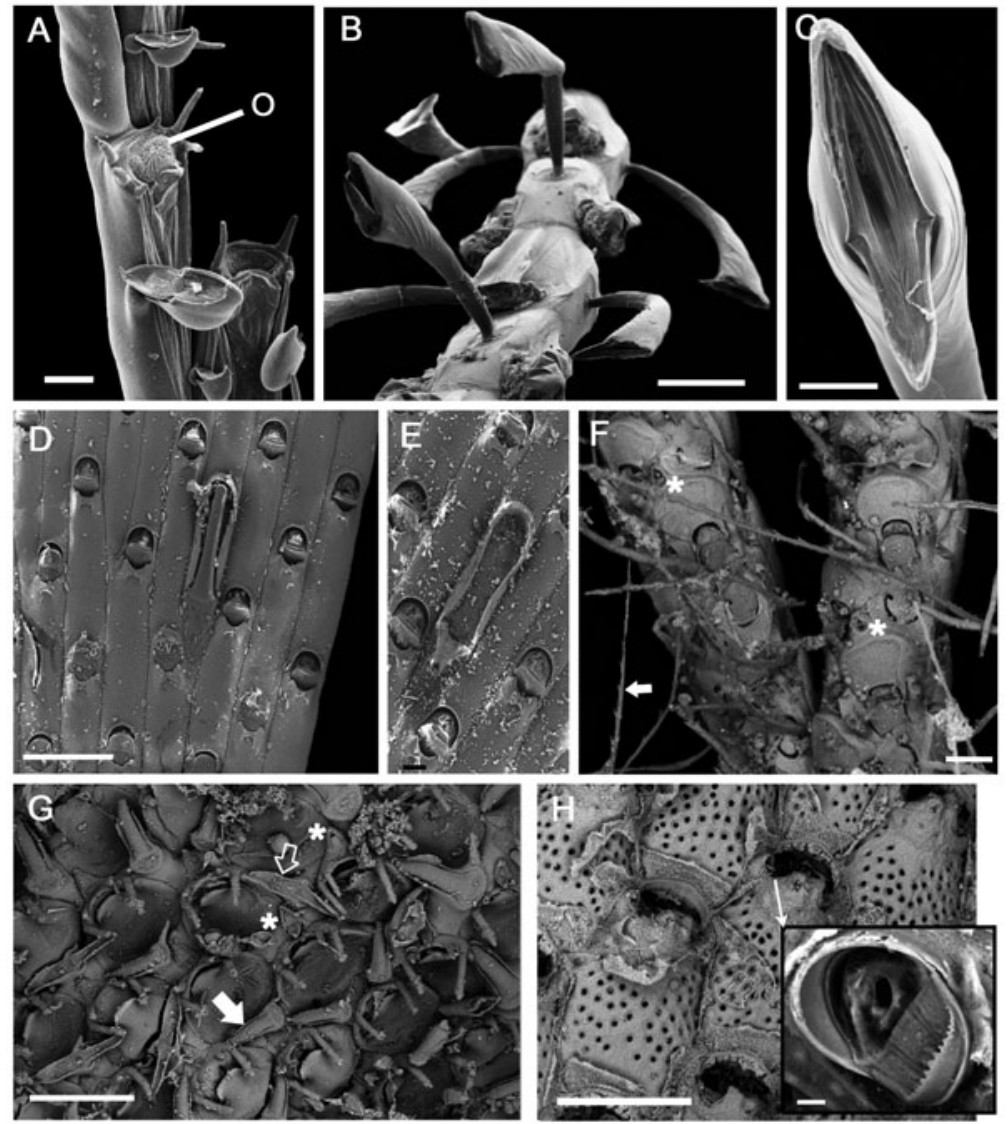

Fig. 1. Avicularian polymorphism: (A) Bugula flabellata colony with autozooids and bird's head form of adventitious avicularia; $(\mathrm{O})=$ orifice of autozooid. Scale bar $=100 \mu \mathrm{m}_{i}$ (B) Nordgaardia cornucopioides colony with autozooids and adventitious avicularia. Scale bar $=200 \mu \mathrm{m}_{i}(\mathrm{C})$ adventitious avicularium of $N$. cornucopioides. Scale bar $=50 \mu m_{\text {; }}$ (D) Euthyroides jellyae colony and vicarious avicularium. Scale bar $=500 \mu \mathrm{m}_{i}(\mathrm{E})$ vicarious avicularium of E. jellyae. Scale bar $=100 \mu \mathrm{m}$; $(\mathrm{F})$ Caberea sp. colony with vibracula (arrow, vibraculum setae) and adventitious avicularium $\left({ }^{*}\right)$. Scale bar $=$ $100 \mu \mathrm{m}_{i}$ (G) Chaperiopsis cf. rubida colony with adventitious (*) and interzooidal (open arrow, mandible open; filled arrow, mandible closed) avicularia. Scale bar $=500 \mu \mathrm{m}_{i}(\mathrm{H})$ Mucropetraliella $\mathrm{n}$. sp. colony with small suboral adventitious avicularium. Scale bar $=100 \mu \mathrm{m}$. Insert, avicularium. Scale bar $=10 \mu \mathrm{m}$. (A) $-(\mathrm{C})$ after Carter et al. (2008) 
ficult, but recent advances in microscopy (e.g. scanning electron microscopy (SEM), transmission electron microscopy (TEM), laser scanning confocal) provide new opportunities to better understand avicularian morphological diversity.

A modular construction pervades every level of biological organisation (Nelson 2004), and bryozoans are an excellent group to study the implications of such a design (Hageman 2003, Hughes 2005). In this paper we describe avicularian morphological diversity and patterns of avicularian morphometrics in cheilostomes collected from a range of depths (habitats) around New Zealand (NZ). Given the paucity of knowledge about avicularia, we suggest that the comparative approach (e.g. Harvey \& Pagel 1991) is fundamentally important in understanding the evolution and ecology of this phenotypic level of modularity in bryozoans. Whilst no formal phylogeny exists for cheilostome bryozoans, our analyses reveal significant congruence of morphometric pattern for a wide array of taxa. Also, morphometric analyses of autozooid and polymorph characters have been successfully employed in species determination, showing significant discriminating power and revealing unexpectedly large numbers of cryptic species (Cheetham 1973, Jackson \& Cheetham 1990). Therefore, we employed multivariate statistical analyses to infer morphometric congruence and dissimilarity among the 4 types of avicularia; we then compared morphological attributes across taxonomic groups, within and between avicularian types and depth ranges. Our findings indicate that (1) intraspecific variability in avicularian morphometrics is common, (2) morphometric distinctions are not significant among 3 types of avicularia (adventitious, interzooidal and vicarious), (3) vibracula are morphometrically distinct and invariable, (4) selection has favoured the morphological diversification of adventitious types, and (5) densities of avicularia within colonies do not vary over different depth ranges.

\section{MATERIALS AND METHODS}

Distribution and collection of bryozoans. Bryozoans were collected from localities around NZ between April 2005 and January 2008 from depths of 0 to $1000 \mathrm{~m}$. Intertidal bryozoans were collected by hand, and subtidal (4-8 m) samples were collected by National Institute of Water and Atmospheric Research (NIWA)

\footnotetext{
${ }^{20^{\circ}}$
}

SCUBA divers. Deep-sea bryozoans (600- $1000 \mathrm{~m})$ were collected from the Graveyard Seamount Complex on the Chatham Rise by epibenthic sled onboard the NIWA RV 'Tangaroa' during May and June 2006. Where no depth was recorded at collection, depth ranges were obtained from historical records (if available). In total, 38 species representing 11 superfamilies were examined (Fig. 2, Table 1).

SEM. Intertidal and subtidal colonies were initially relaxed in $7 \% \mathrm{MgCl}_{2}$ for 20 min prior to fixation in $1 \%$ $\mathrm{OsO}_{4}$ in $0.1 \mathrm{M}$ sodium cacodylate buffer $(7.4 \mathrm{pH})$ and $10.26 \%$ sucrose $(\mathrm{CAB} ; 750 \mathrm{mOsMol})$ for $2 \mathrm{~h}$ (Nielsen 2002). Colonies were then washed 3 times in CAB for 10 min each wash, dehydrated in a graded ethanol/ acetone series ending in $100 \%$ acetone and critical point dried. Many colonies were too large to mount directly onto SEM stubs, and in those instances fragments of the colony were mounted. Samples were then coated in either carbon or gold in a sputter coater prior to being viewed in a Jeol 6500, Jeol 5300 LV, or LEO 440 SEM.

Deep-sea bryozoans (600-1000 m) were relaxed (as described above) and fixed in $2.5 \%$ gluteraldehyde on board the research vessel and then placed in airtight

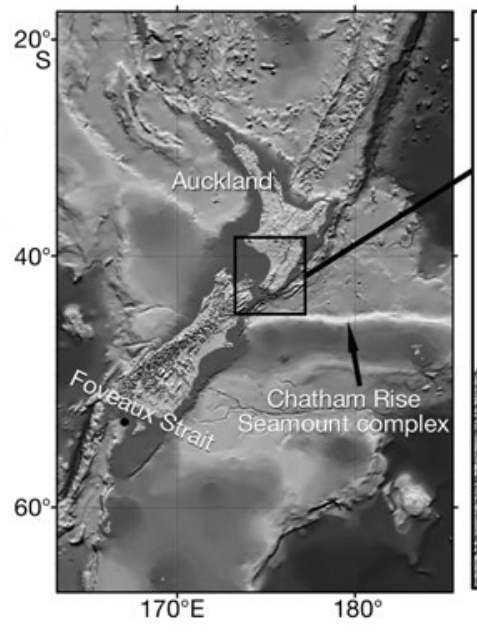

Fig. 2. Map of New Zealand and the respective collection sites for the species of bryozoans studied. Maps courtesy of NIWA

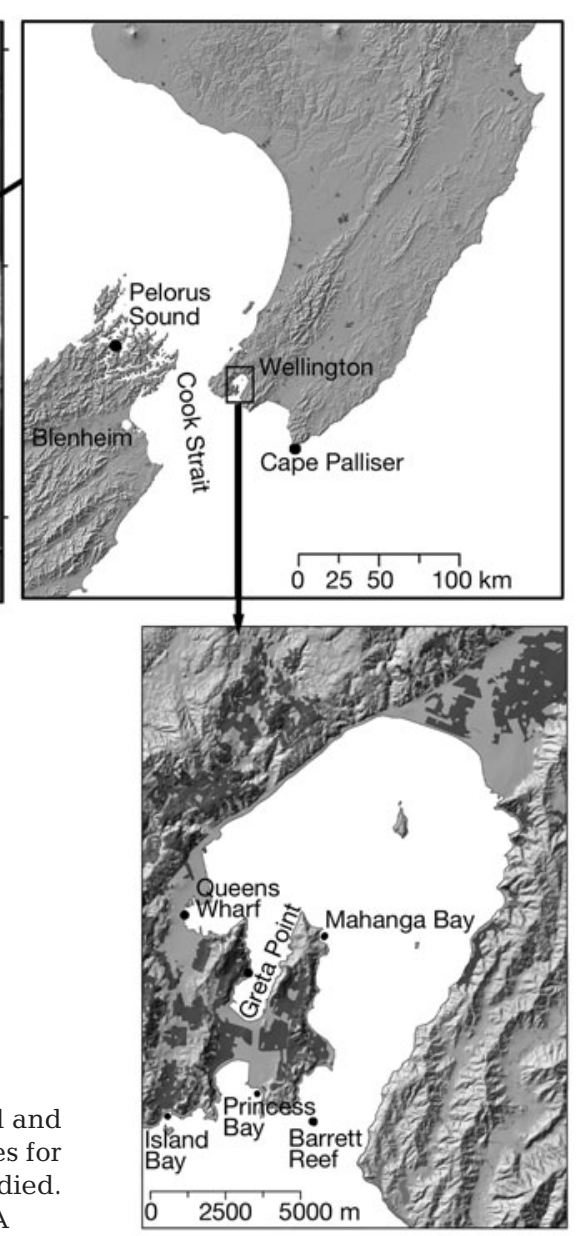


plastic containers containing filtered seawater for storage purposes ( 5 to $25 \mathrm{~d}$ ). Once back onshore, colonies were post-fixed in $1 \%$ osmium in $\mathrm{CAB}$ and then taken through the dehydration process described above.

Digital images were imported and analysed using Jeol SemaFore Image Analysis software. All avicularia per image were measured. To maximise information return and to minimise distortion (orientation) problems, 1 to 5 images per avicularium and 1 to 25 images of that avicularian type per species were taken. The number of measurements obtained per species was variable due to avicularia having their mandibles open (usable image) or closed (unusable image). Intercolony inconsistencies in the occurrence of avicularia in some species, and number of colonies actually collected, also added to the variability.
Terminology. Type of avicularia refers to adventitious, interzooidal, vicarious or vibracula. Form of avicularia refers to the overall shape of that avicularian type. For example, species of Bugula have an adventitious type of avicularia (the avicularium is derived from the frontal wall of the autozooid) which has a bird'shead form (resembles a miniature bird's head).

Morphometrics. Avicularia were grouped into 4 types: adventitious, interzooidal, vibracula and vicarious. The vibracula collected in this study are adventitious in location but are characteristically different in morphology owing to their elongated, hair-like mandibles. They were separated from the adventitious group for comparative (analytical) purposes and for ease of interpretation. This distinction allowed for finescale morphological analysis to be resolved (i.e. fea-

Table 1. Species of bryozoans studied, depth and collection sites from around New Zealand: (BR) Barrett Reef; (CP) Cape Palliser; (CR) Chatham Rise seamount complex; (GP) Greta Point; (MB) Mahanga Bay; (IB) Island Bay; (FS) Foveaux Strait; (PB) Princess Bay; (QW) Queens Wharf

\begin{tabular}{|c|c|c|c|}
\hline Species & Superfamily & Site & Depth $(\mathrm{m})$ \\
\hline Arachnopusia unicornis (Hutton, 1873) & Arachnopusioidea & $\mathrm{BR} / \mathrm{MB}$ & 8 \\
\hline Beania magellanica (Busk, 1852) & Buguloidea & $\mathrm{BR} / \mathrm{IB}$ & $4-8$ \\
\hline Bicellariella ciliata (Linnaeus, 1758) & Buguloidea & FS & - \\
\hline Bugula flabellata (Thompson in Gray, 1848) & Buguloidea & MB/QW & $0.1-0.5$ \\
\hline Caberea rostrata Busk, 1884 & Buguloidea & BR/IB & $4-8$ \\
\hline Caberea zelandica (Gray, 1843) & Buguloidea & $\mathrm{BR} / \mathrm{FS}$ & 8 \\
\hline Caberea sp. & Buguloidea & IB & $4-6$ \\
\hline Catenicella pseudoelegaens Gordon, 2009 & Catenicelloidea & IB/QW & $0.2-6$ \\
\hline Cellaria pilosa (Kirchenpauer, 1869) & Cellarioidea & $\mathrm{PB}$ & Drift \\
\hline Cellaria tenuirostris (Tennison-Woods, 1880) & Cellarioidea & $\mathrm{BR}$ & 8 \\
\hline Celleporina grandis Gordon, 1989 & Celleporoidea & BR & 8 \\
\hline Celleporina wellingtonensis Gordon, 2009 & Celleporoidea & $\mathrm{PB}$ & Drift \\
\hline Chaperiopsis cf. rubida (Hincks, 1881) & Calloporoidea & $\mathrm{BR}$ & 8 \\
\hline Chiastosella exuberans Gordon, 1989 & Schizoporelloidea & $\mathrm{CR}$ & $600-1000$ \\
\hline Chiastosella watersi Stach, 1937 & Schizoporelloidea & $\mathrm{BR}$ & 8 \\
\hline Claviporella aurita (Busk, 1852) & Catenicelloidea & IB & $4-6$ \\
\hline Costaticella bicuspis (Gray, 1843) & Catenicelloidea & FS & $20-200$ \\
\hline Costaticella solida (Levinsen, 1909) & Catenicelloidea & $\mathrm{PB}$ & 134 \\
\hline Cribricellina cribraria (Busk, 1852) & Catenicelloidea & IB & $4-6$ \\
\hline Escharoides angela (Hutton, 1873) & Lepralielloidea & GP/IB & $0.3-6$ \\
\hline Escharoides excavata (MacGillvray, 1860) & Lepralielloidea & $\mathrm{BR}$ & 8 \\
\hline Euthyroides jellyae Levinsen, 1909 & Cribrilinoidea & $\mathrm{BR}$ & 8 \\
\hline Exochella armata (Hincks, 1882) & Lepralielloidea & $\mathrm{IB} / \mathrm{PB}$ & $4-6$ \\
\hline Exochella jullieni Gordon, 1989 & Lepralielloidea & CR/FS & $600-1000$ \\
\hline Hippomenella vellicata (Hutton, 1873) & Schizoporelloidea & FS & $25-300$ \\
\hline Microporella agonistes Gordon, 1984 & Schizoporelloidea & FS/IB & $4-6$ \\
\hline Mucropetraliella n.sp. & Schizoporelloidea & $\mathrm{FS} / \mathrm{IB}$ & $4-6$ \\
\hline Nordgaardia cornucopioides d'Hondt, 1983 & Buguloidea & $\mathrm{CR}$ & $600-1000$ \\
\hline Odontionella cyclops (Busk, 1854) & Calloporoidea & $\mathrm{BR} / \mathrm{CP} / \mathrm{FS}$ & $1-8$ \\
\hline Opaeophora lepida (Hincks, 1881) & Microporoidea & FS & 54 \\
\hline Osthimosia sirena Gordon, 2009 & Celleporoidea & $\mathrm{PB}$ & Drift \\
\hline Parkermavella n.sp. & Smittinoidea & CR & $600-1000$ \\
\hline Reteporella aurantium Gordon, 2009 & Celleporoidea & IB & $4-6$ \\
\hline Reteporella gracilis Gordon, 1989 & Celleporoidea & CR & $600-1000$ \\
\hline Rhynchozoon zealandicum Gordon, 2009 & Celleporoidea & GP & 0.2 \\
\hline Scrupocellaria ornithorhyncus Thompson, 1858 & Buguloidea & $\mathrm{BR}$ & 8 \\
\hline Stephanollona scintillans (Hincks, 1885) & Celleporoidea & FS/CR & $600-1000$ \\
\hline Tricellaria catalinensis (Robertson, 1905) & Buguloidea & MB & 4 \\
\hline
\end{tabular}


tures not discernable or measurable at light-microscopic level). Their classification as a separate group also allowed for the testing of specific hypotheses about avicularian structure and type (e.g. discriminant function analysis, DFA, requires pre-designated groups for the assignment testing).

The 6 morphometric features measured for analysis from the digital images were: length of avicularium (Lav), width of avicularium (Wav), length of palate (Lpal), width of palate (Wpal), length of orifice (Lo) and width of orifice (Wo) (Fig. 3).

Statistical analyses. Repeated measurements from different images of an avicularium were averaged to obtain a single mean value for each of the 6 variables (Lav, Wav, Lpal, Wpal, Lo, and Wo) per avicularium. Because morphological traits of avicularia co-vary (Carter et al. 2008), each variable was $\log _{10}$ transformed; each was then standardised (except Lav) by dividing by $\log _{10}$ Lav (Gardner 2004). The 5 transformed and standardised variables are prefixed with ' $s$ '. The standardisation of morphometric data emphasises shape whilst ensuring the properties of the measurements are invariant to scale, location and orientation (Marcus \& Corti 1996). The following 5 variables were therefore analysed: sWav $\left(=\log _{10}\right.$ Wav/ $\left.\log _{10} \mathrm{Lav}\right)$, sLpal (= $\left.\log _{10} \mathrm{Lpal} / \log _{10} \mathrm{Lav}\right)$, sWpal (= $\log _{10} \mathrm{Wpal} /$ $\left.\log _{10} \mathrm{Lav}\right)$, sLo $\left(=\log _{10} \mathrm{Lo} / \log _{10} \mathrm{Lav}\right)$ and sWo $\left(=\log _{10} \mathrm{Wo} /\right.$ $\left.\log _{10} \mathrm{Lav}\right)$.

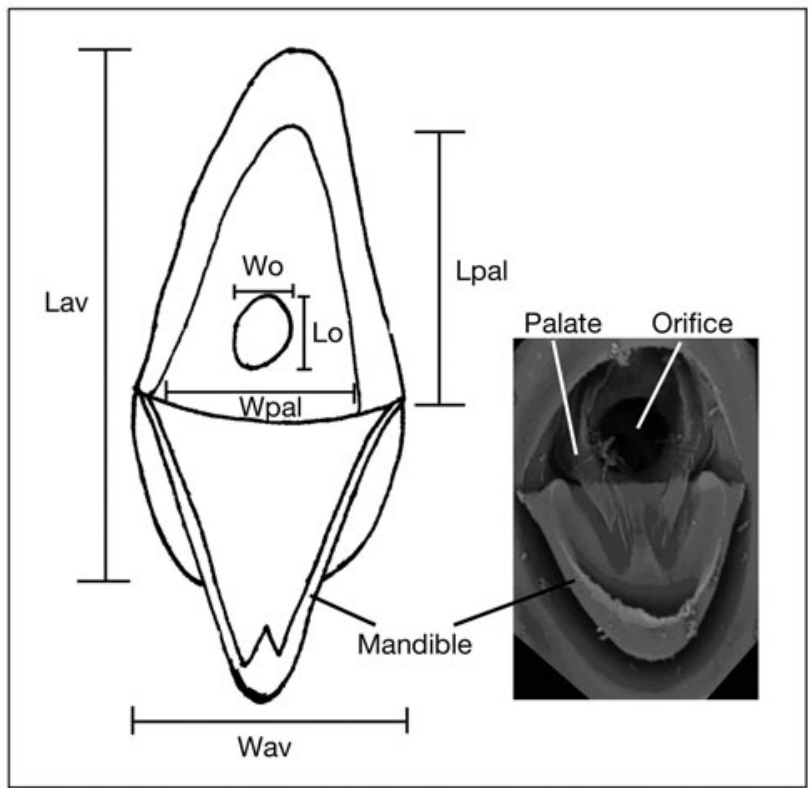

Fig. 3. Frontal view (left) of an avicularium with morphological variables annotated: length of avicularium (Lav), width of avicularium (Wav), length of palate (Lpal), width of palate (Wpal), length of orifice (Lo), width of orifice (Wo). Right is a scanning electron micrograph of an avicularium in order to place the diagrammatic measurements into context
Multivariate statistical analysis of the 5 standardised variables was employed to examine morphometric variability among depths (<8 m, 20-300 m, 60-1000 m), among all 4 avicularian types (adventitious, interzooidal, vicarious, vibracula) and among species within a superfamily (Calloporoidea, Buguloidea, Catenicelloidea, Arachnopusioidea, Lepralielloidea, Schizoporelloidea, Celleporoidea, Cellarioidea). The Bray-Curtis similarity index was used to summarise multi-trait morphometric variability across a range of species and avicularian types. This similarity matrix was subsequently employed in non-parametric multidimensional scaling (MDS) and an analysis of similarities (ANOSIM) to test statistically the null hypothesis that there is no significant morphometric difference among avicularia. The MDS and ANOSIM analyses were carried out using the PRIMER v.6 (PRIMER-E) statistical package (Clarke \& Gorley 2006). A DFA was employed as an assignment test to determine what percentage of avicularia could be correctly assigned to their avicularian type based on their morphological variability and known group of origin. DFA calculates the Mahalanobis squared distance $\left(D^{2}\right)$ and its statistical significance between a given avicularium and each type of avicularia. Low values of $D^{2}$ indicate little distance (= difference) between/among groups, whereas high values of $D^{2}$ indicate greater difference between/among groups. Formal statistical testing of $D^{2}$ is derived from the Wilks' lambda statistic which varies between 0 (perfect discrimination, no similarity) to 1 (no discrimination, total similarity). The DFA was carried out using Statistica v.7 (StatSoft 2005).

Avicularian density within colonies. Colony area and counts of avicularia were calculated from SEM digital images of colonies using the Jeol SemaFore Image Analysis software. Between 1 and 9 colony images per species were analysed enabling intercolony patterns in avicularian density to be discerned where possible. Data were collated in a Microsoft Excel spreadsheet and transferred to Statistica v.7 to construct a box and whisker plot of avicularian densities.

\section{RESULTS}

\section{Avicularian morphometric variation among superfamilies}

A total of 35 species were grouped into 8 superfamilies for comparative analyses. Parkermavella n. sp. Opaeophora lepida and Euthyroides jellyae were the sole representatives of their respective superfamilies (each also possessed 1 type of avicularium) and therefore excluded from this analysis. 
The MDS plot for the Calloporoidea showed an overall minimum similarity of $60 \%$ in avicularian morphometrics. Chaperiopsis cf. rubida had adventitious and interzooidal avicularia, whilst Odontionella cyclops had adventitious only. The morphometric variability of the avicularia of $O$. cyclops overlapped with the adventitious type of $C$. cf. rubida at the $80 \%$ similarity level. The interzooidal avicularia of $C$. cf. rubida were morphometrically distinct from the adventitious types with the majority forming a discrete second group (Fig. 4A, B). These different groupings were supported by the ANOSIM ( $\mathrm{p} \leq 0.001$; global $\mathrm{R}=0.388$ ).

The MDS plot for the Buguloidea showed avicularian-specific clustering, with the adventitious types having an overall minimum $60 \%$ morphometric similarity, and the vibracular $80 \%$ similarity. The adventitious avicularia were further split into 3 clusters, each with $80 \%$ similarity (Fig. 4C,D). Separation of these clusters was well supported by the ANOSIM ( $\mathrm{p} \leq 0.001$; global $\mathrm{R}=0.289$ ). Individual values for the ANOSIM pairwise comparisons of species showed that morphometric dissimilarity was statistically significant between the avicularia of Nordgaardia cornucopioides and all other species ( $p<0.05$ for all pairwise comparisons). There was a high degree of morphometric similarity between the bird's-head form of avicularia in Beania magellanica and Bicellariella ciliata, between the bird's-head form of B. magellanica and Bugula flabellata and between the avicularia of Caberea zelandica and Caberea sp. ( $\mathrm{p}>0.05$ and $\mathrm{R}=0$ for each pairwise comparison indicating no significant differences).

Within the Cellarioidea, 2 species-specific clusters were revealed, indicating a high degree of intraspecific morphometric similarity (90\%) (Fig. 4E). Morphometric similarity between the vicarious avicularia of Cellaria pilosa and C. tenuirostris was $80 \%$ and ANOSIM supported the distinctness of the 2 clusters ( $\mathrm{p}<0.05$; global $\mathrm{R}=0.924$ ).

The avicularia of the catenicellids were all adventitious with an overall minimum morphometric similarity of $60 \%$ (Fig. 4F). Although, 2 further avicularianspecific clusters were revealed, each with a high degree of morphometric similarity $(80 \%)$, the ANOSIM indicated that these were not significantly different ( $\mathrm{p}>0.05$; global $\mathrm{R}=0$ ).

Arachnopusia unicornis was the sole representative of the Arachnopusioidea. The MDS plot showed a high degree of similarity (80\%) between adventitious and interzooidal types within this species (Fig. 5A), and the ANOSIM indicated there was no significant difference in morphometric variation between these types $(\mathrm{p}>$ 0.05 ; global $\mathrm{R}=0.279$ ) .

Members of the Lepralielloidea all had adventitious avicularia. The MDS plot showed an overall $60 \%$ morphometric similarity among avicularia. Two further clusters both contained avicularia of $80 \%$ morphometric similarity (Fig. 5B), the distinctiveness between them being supported by the ANOSIM ( $p \leq 0.001$; global $\mathrm{R}=0.501)$. The individual values for the ANOSIM pairwise comparisons of species showed that morphometric dissimilarity was statistically significant between the avicularia of Escharoides angela and Exochella jullieni ( $<<0.05 ; \mathrm{R}=0.9$ ). Intraspecific morphometric variability was evident for Exochella armata and Exochella jullieni as illustrated by the multigrouping for Exochella armata and slight overlap in points between the 2 species. Despite this, the individual pairwise values showed the 2 species were significantly dissimilar in morphometrics ( $\mathrm{p} \leq 0.001$; global $\mathrm{R}=0.339$ ).

Members of the Schizoporelloidea all had adventitious avicularia. The MDS plot showed an overall $60 \%$ morphometric similarity among avicularia. Two further clusters both contained avicularia of $80 \%$ morphometric similarity (Fig. 5C), the difference between them being supported by ANOSIM ( $\mathrm{p}<0.001$; global $\mathrm{R}=$ 0.506). The individual values for the ANOSIM pairwise comparisons of species showed that morphometric dissimilarity was statistically significant between the avicularia of Chiastosella exuberans and C. watersi $(\mathrm{p}<$ $0.05 ; \mathrm{R}=0.70$ ) and between Mucropetraliella $\mathrm{n}$. sp. and C. exuberans ( $\leq 0.001 ; \mathrm{R}=0.902)$.

The MDS plot for the Celleporoidea showed an overall $60 \%$ morphometric similarity among avicularia. Two distinct clusters, each containing avicularia of $80 \%$ morphometric similarity (Fig. 5D,E), were supported by the ANOSIM ( $\mathrm{p} \leq 0.001$; global $\mathrm{R}=0.29$ ). This superfamily consisted of adventitious, interzooidal and vicarious types of avicularia, and therefore had an extensive morphometric range which may have contributed to the low global $\mathrm{R}$ value. The ANOSIM pairwise comparisons of species showed that morphometric dissimilarity was statistically significant between the avicularia of Reteporella aurantium and Stephanollona scintillans ( $\mathrm{p} \leq 0.001 ; \mathrm{R}=0.40$ ), and Reteporella aurantium and Reteporella gracilis ( $\mathrm{p}<$ $0.05 ; \mathrm{R}=0.4)$. The results from the ANOSIM analyses among superfamilies are presented in Table 2.

\section{Avicularian morphometric variation among types}

DFA revealed that sWav, sLo, sWo, and sLpal were all significant contributors to morphometric variability ( $p \leq 0.001$ in all cases; Table 3 ). Less so, but still significant, was width of palate (sWpal) $(\mathrm{p}<0.05)$. A total of $84 \%$ of avicularia were classified correctly to type (Table 4), in large part because $100 \%$ of adventitious avicularia $(\mathrm{n}=278)$ and $100 \%$ of vibracula $(\mathrm{n}=11)$ were classified correctly. Only $3.5 \%$ of vicarious types 


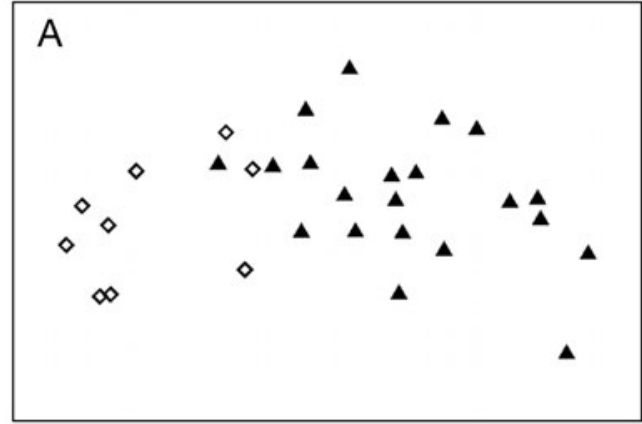

A Adventitious $\diamond$ Interzooidal

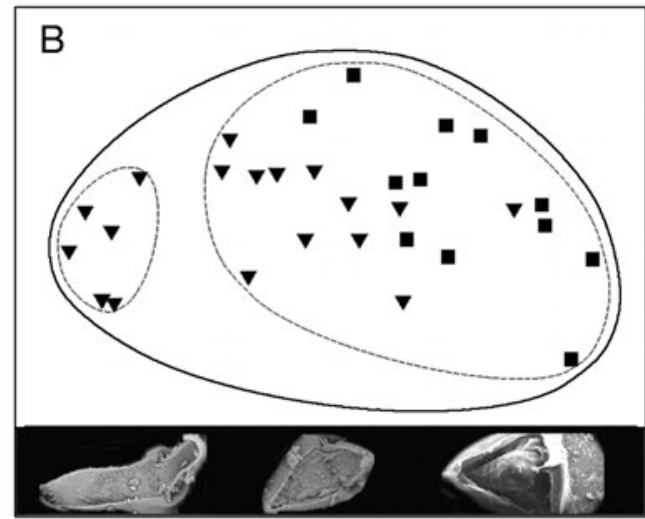

- Chaperiopsis cf. rubida - Odontionella cyclops

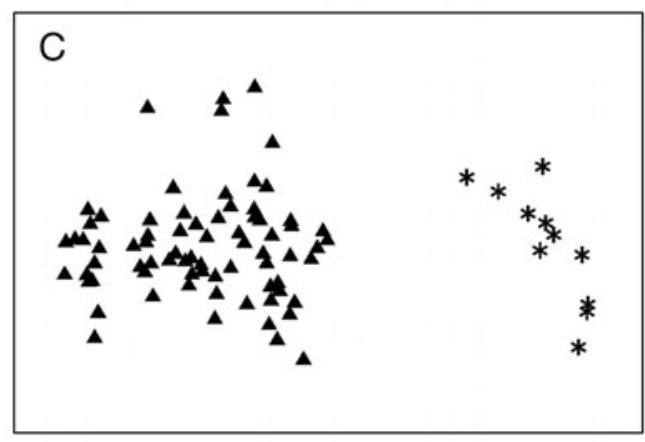

\ Adventitious
* Vibracula

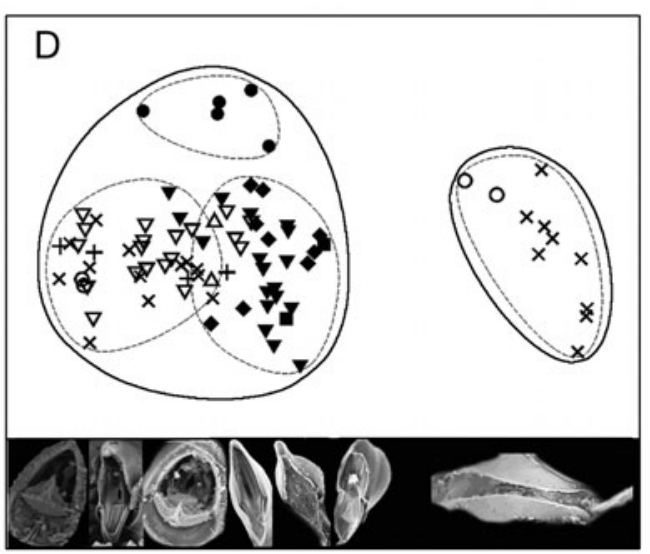

+ Caberea rostrata

- Caberea sp.

$\nabla$ Tricellaria

catalinensis

- Nordgaardia

- Bicellariella ciliata

$\times$ Caberea zelandica

$\checkmark$ Beania magellanica

$\triangle$ Scrupocellaria ornithorhyncus

- Bugula flabellata
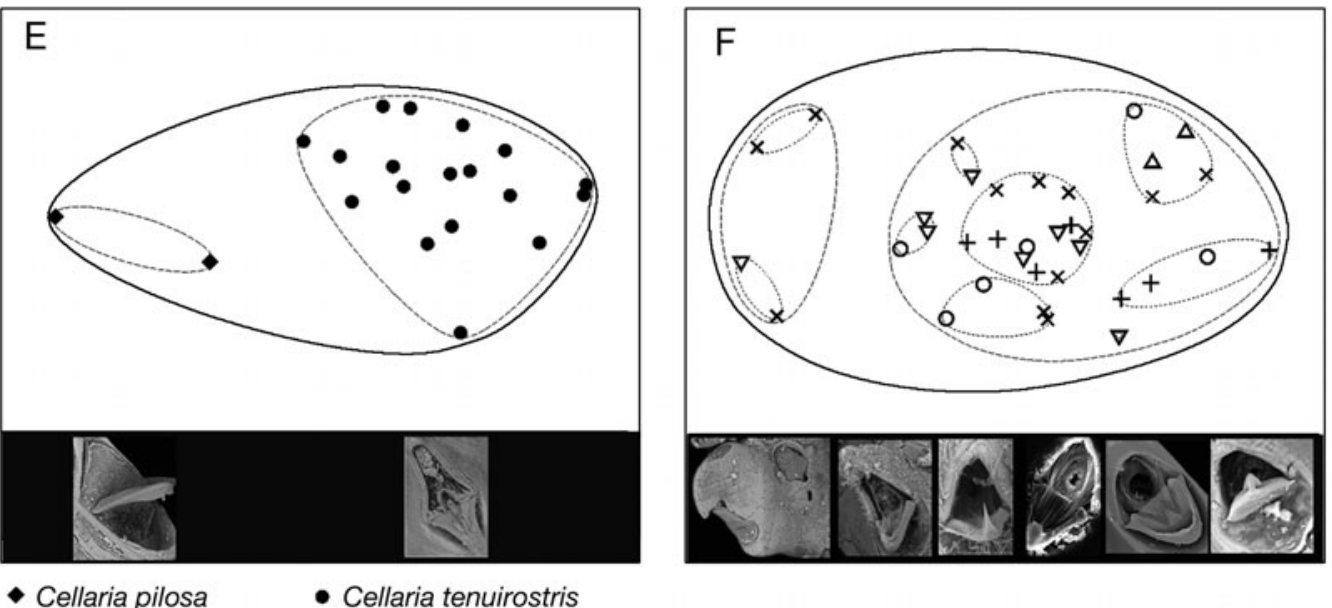

Cribricellina cribraria

- Costaticella bicuspis

+ Catenicella pseudoelegans

$\Delta$ Costaticella solida

$\times$ Claviporella aurita

Fig. 4. Non-parametric MDS ordination plots for standardised (s) and $\log _{10}$ transformed avicularian morphometrics (width of avicularia, sWav; length of palate, sLpal; width of palate, sWpal; length of orifice, sLo; width of orifice, sWo) among superfamilies. $\mathrm{n}$ = number of avicularia. (A,B) Calloporoidea: (A) avicularian type; $(B)$ species $(\mathrm{n}=30)$. Stress level: 0.08. Similarity: $(-)$ 60\%, (--) $80 \%$. Images beneath (B) (left to right): interzooidal avicularium of Chaperiopsis cf. rubida, adventitious avicularia of $C$. cf. rubida and Odontionella cyclops. (C,D) Buguloidea: (C) avicularian type; (D) species (n = 85). Stress level: 0.07. Similarity: $(-)$ $60 \%,(--)$ 80\%. Images beneath (D) (left to right): adventitious avicularia of Caberea zelandica, Tricellaria catalinensis, Caberea rostrata, Nordgaardia cornucopioides, Beania magellanica, Bugula flabellata and vibraculum of Caberea sp. (E) Cellarioidea ( $\mathrm{n}=21$ ). Stress level, 0.06. Similarity: (-) 80\%, (--) $90 \%$. Images beneath (E) (left to right): vicarious avicularia of Cellaria pilosa and C. tenuirostris. $(\mathrm{F})$ Catenicelloidea $(\mathrm{n}=36)$. Stress level, 0.12 . Similarity: $(-) 60 \%,(---) 80 \%,(\cdots \cdots)$.... $90 \%$. Images beneath $(\mathrm{F})$ (left to right): large adventitious avicularium of Claviporella aurita, adventitious avicularia of Cribricellina cribraria, C. aurita, 


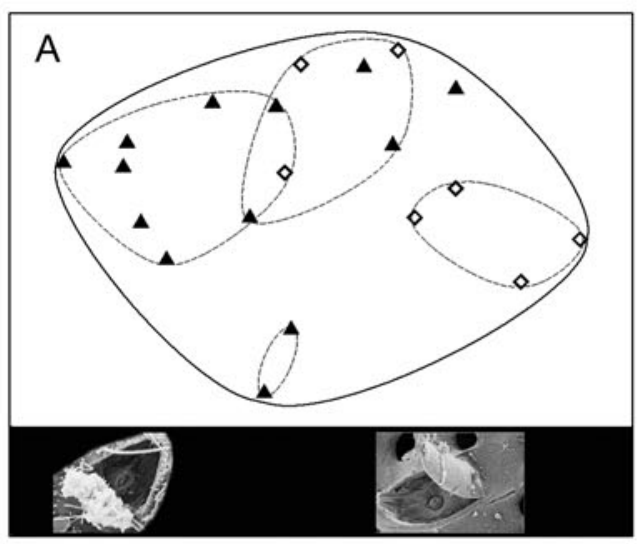

A Adventitious

$\diamond$ Interzooidal

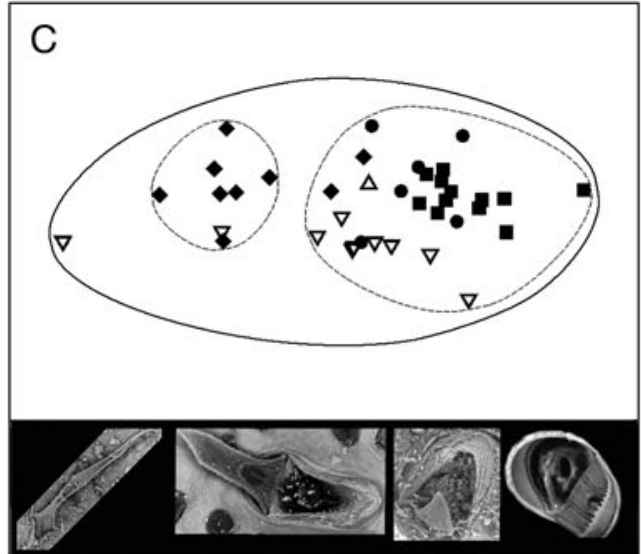

$\nabla$ Microporella agonistes

- Chiastosella watersi

$\Delta$ Hippomenella vellicata
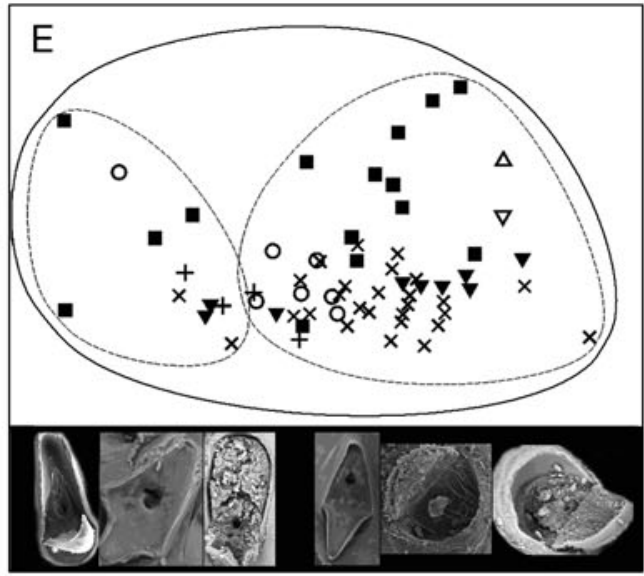

- Stephanollona scintillans

$\times \begin{aligned} & \text { Reteporella } \\ & \text { aurantium }\end{aligned}$

$\Delta$ Celleporina grandis

+Reteporella gracilis

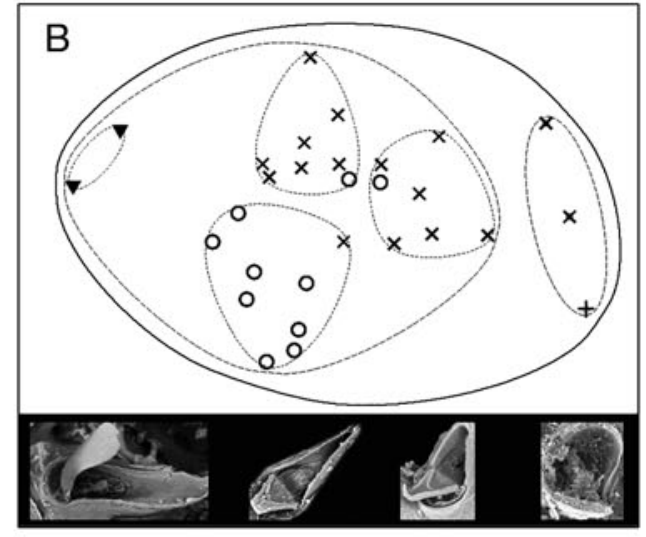

- Escharoides angela

- Exochella jullieni

$\times$ Exochella armata

+ Escharoides excavata

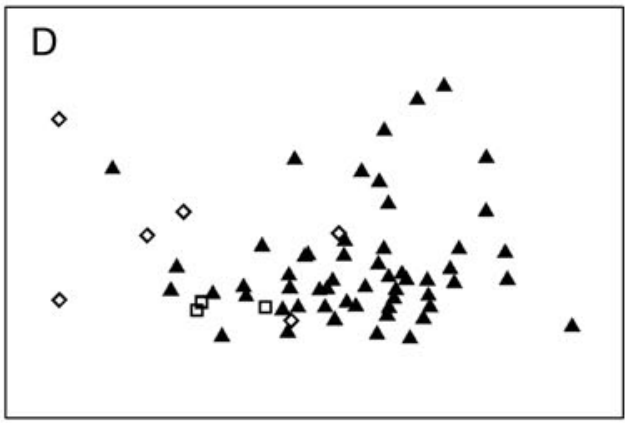

- Adventitious

$\diamond$ Interzooidal

- Vicarious

Fig. 5. Non-parametric MDS ordination plots for standardised (s) and $\log _{10}$ transformed avicularian morphometrics (width of avicularia, sWav; length of palate, sLpal; width of palate, sWpal; length of orifice, sLo; width of orifice, sWo) among superfamilies. $\mathrm{n}=$ number of individual avicularia. (A) Arachnopusioidea: avicularian type $(\mathrm{n}=20)$. Stress level: 0.13 . Similarity: (-) 80\%, (---) $90 \%$. Images beneath (A) (left to right) adventitious and interzooidal avicularia of Arachnopusia unicornis. (B) Lepralielloidea $(\mathrm{n}=29)$. Stress level: 0.08. Similarity: (-) 60\%, (---) 80\%, (…...) $90 \%$. Images beneath (B) (left to right): adventitious avicularia of Escharoides angela, Exochella jullieni, Exochella armata and Escharoides excavata. (C) Schizoporeloidea $(\mathrm{n}=38)$. Stress level: 0.06 . Similarity: (-) 60\%, (---) 80\%. Images beneath (C) (left to right): adventitious avicularia of Microporella agonistes, Chiastosella exuberans, Chiastosella watersi and Mucropetraliella n. sp. (D,E) Celleporoidea: (D) avicularian type; (E) species $(n=64)$. Stress level: 0.11. Similarity: $(-) 60 \%,(---)$ $80 \%$. Images beneath (E) (left to right): interzooidal avicularium of Stephanollona scintillans, large adventitious avicularium of Rhynchozoon aurantium, vicarious avicularium of Osthimosia sirena, adventitious avicularia of $R$. aurantium, $S$. scintillans and $O$. sirena 
Table 2. Significance (p) and global R values for the species pairwise analysis of similarity (ANOSIM) among superfamilies for standardised (s) and $\log _{10}$ transformed avicularian morphometrics: width of avicularia (sWav); length of palate (sLpal); width of palate (sWpal); length of orifice (sLo); width of orifice (sWo). $\mathrm{n}=$ number of avicularia (total $\mathrm{n}=323$ ). Sole representatives of superfamilies with 1 type of avicularia (Parkermavella n. sp., Opaeophora lepida and Euthyroides jellyae) are missing from this analysis

\begin{tabular}{|c|c|c|c|c|c|}
\hline Superfamily & $\mathrm{n}$ & $\begin{array}{l}\text { Avicularian } \\
\text { type (s) }\end{array}$ & $\begin{array}{l}\text { Morphometric } \\
\text { similarity }(\%)\end{array}$ & $\mathrm{p}$ & $\begin{array}{c}\text { Global } \\
\text { R }\end{array}$ \\
\hline Calloporoidea & 30 & $\begin{array}{l}\text { Adventitious } \\
\text { Interzooidal }\end{array}$ & 60 & $\leq 0.001$ & 0.388 \\
\hline Buguloidea & 85 & $\begin{array}{l}\text { Adventitious } \\
\text { Vibracular }\end{array}$ & 60 & $\leq 0.001$ & 0.289 \\
\hline Cellarioidea & 21 & Vicarious & 80 & $<0.05$ & 0.924 \\
\hline Catenicelloidea & 36 & Adventitious & 60 & $>0.05$ & 0 \\
\hline Arachnopusioidea & 20 & Adventitious & 80 & $>0.05$ & 0.279 \\
\hline Lepralielloidea & 29 & Adventitious & 60 & $\leq 0.001$ & 0.501 \\
\hline Schizoporelloidea & 38 & Adventitious & 60 & $\leq 0.001$ & 0.506 \\
\hline Celleporoidea & 64 & $\begin{array}{l}\text { Adventitious } \\
\text { Interzooidal } \\
\text { Vicarious }\end{array}$ & 60 & $\leq 0.001$ & 0.290 \\
\hline
\end{tabular}

types $\left(D^{2}=42.79\right)$, followed by interzooidal versus vibracular types $\left(D^{2}=\right.$ 36.19).

\section{Avicularian density within colonies}

Species with the greatest densities of avicularia were those with more than 1 type of avicularia (e.g. adventitious and vibracula, adventitious and vicarious, adventitious and interzooidal), whilst those with only vicarious avicularia had the lowest densities. The density of avicularia in all species with either vicarious or interzooidal was $<5 \mathrm{~mm}^{-2}$, whilst $75 \%$ of adventitious and $95 \%$ of combined ( $>1$ type) displayed densities $\geq 5 \mathrm{~mm}^{-2}$ (Fig. 6). Caberea sp. had the greatest density of avicularia when adventitious and vibracula were con-

Table 3. Discriminant function analysis of standardised (s) and $\log _{10}$ transformed avicularian morphometrics: width of avicularia (sWav); length of palate (sLpal); width of palate (sWpal); length of orifice (sLo); width of orifice (sWo). Total $\mathrm{n}=345$

\begin{tabular}{|c|c|c|}
\hline $\begin{array}{l}\text { Morphological } \\
\text { variables }\end{array}$ & Wilks' lambda & $\mathrm{p}$ \\
\hline sWav & 0.488 & $\leq 0.001$ \\
\hline sLpal & 0.403 & $\leq 0.001$ \\
\hline sWpal & 0.394 & $<0.050$ \\
\hline sLo & 0.434 & $\leq 0.001$ \\
\hline sWo & 0.400 & $\leq 0.001$ \\
\hline
\end{tabular}

( $\mathrm{n}=28$ ) were classified correctly (for Cellaria tenuirostris only): the remainder was classified as adventitious. All interzooidal $(n=28)$ were classified incorrectly. All pairwise comparisons of avicularian type using $D^{2}$ were significantly different $(\mathrm{p}<0.05$ in all cases), except for interzooidal versus vicarious $\left(D^{2}=\right.$ $0.6 ; \mathrm{p}>0.05$ ) (Table 5). The largest morphometric difference was between adventitious versus vibracular sidered in combination $\left(52.17 \mathrm{~mm}^{-2} ; \mathrm{n}=1\right)$. Caberea rostrata $\left(29.48 \pm 19 \mathrm{SD} \mathrm{mm}^{-2} ; \mathrm{n}=2\right)$ and $C$. zelandica (33.6 $\pm 4 \mathrm{~mm}^{-2} ; \mathrm{n}=7$ ) also had high densities of avicularia when adventitious and vibracular types were considered in combination.

Species with only adventitious types had a greater density of avicularia than those with only interzooidal or only vicarious types. Nordgaardia cornucopioides $\left(26.63 \pm 9 \mathrm{~mm}^{-2} ; \mathrm{n}=2\right)$ had the greatest density of adventitious avicularia followed by Exochella armata $\left(21.83 \pm 7 \mathrm{~mm}^{-2} ; \mathrm{n}=7\right)$. Species with vicarious avicularia and with the lowest density were Euthyroides jellyae $\left(0.04 \pm 0.02 \mathrm{~mm}^{-2} ; \mathrm{n}=9\right)$, Cellaria pilosa $\left(0.9 \pm 0.4 \mathrm{~mm}^{-2} ; \mathrm{n}=4\right)$, and $C$. tenuirostris $\left(2.0 \pm 1.0 \mathrm{~mm}^{-2} ; \mathrm{n}=4\right)$. These species also had negligible inter-colony variability in avicularian densities. Inter-colony variability was evident in C. rostrata, Reteporella gracilis, N. cornucopioides, Escharoides excavata, Stephanollona scintillans, Exochella jullieni and Exochella armata. Low replicate numbers for some species precluded any statistical analysis of avicularian densities.

Table 4. Percentage of individual avicularia identified correctly by discriminant function analysis using standardised (s) and $\log _{10}$ transformed avicularian morphometrics: width of avicularia (sWav); length of palate (sLpal); width of palate (sWpal); length of orifice (sLo); width of orifice (sWo). Total $\mathrm{n}=345$

\begin{tabular}{|c|c|c|c|c|c|c|}
\hline \multirow{2}{*}{$\begin{array}{l}\text { Avicularian } \\
\text { type }\end{array}$} & \multirow[t]{2}{*}{$\mathrm{n}$} & \multirow{2}{*}{$\begin{array}{l}\text { \% classified } \\
\text { correctly }\end{array}$} & \multirow[b]{2}{*}{ Adventitious } & \multicolumn{2}{|c|}{ Classified group } & \multirow[b]{2}{*}{ Vicarious } \\
\hline & & & & Interzooidal & Vibracular & \\
\hline Adventitious & 278 & 100 & 278 & 0 & 0 & 0 \\
\hline Interzooidal & 28 & 0 & 28 & 0 & 0 & 0 \\
\hline Vibracular & 11 & 100 & 0 & 0 & 11 & 0 \\
\hline Vicarious & 28 & 3.5 & 27 & 0 & 0 & 1 \\
\hline
\end{tabular}


Table 5. Mahalanobis distance $\left(D^{2}\right)$ and associated significance level (p) for pairwise comparisons of avicularian types analysed by discriminant function analysis using standardised (s) and $\log _{10}$ transformed avicularian morphometrics: width of avicularia (sWav); length of palate (sLpal); width of palate (sWpal); length of orifice (sLo); width of orifice (sWo). Total $n=345$

\begin{tabular}{|lccc|}
\hline Pairwise comparison & $\begin{array}{c}\text { Mahalanobis } \\
\text { distance }\left(D^{2}\right)\end{array}$ & $\mathrm{F}$ & $\mathrm{p}$ \\
\hline Adventitious vs. interzooidal & 0.90 & 4.5 & $<0.001$ \\
Adventitious vs. vicarious & 1.80 & 9.3 & $<0.001$ \\
Adventitious vs. vibracular & 42.07 & 89.51 & $<0.001$ \\
Interzooidal vs. vicarious & 0.60 & 1.67 & $>0.050$ \\
Interzooidal vs. vibracular & 36.19 & 56.49 & $<0.001$ \\
Vicarious vs. vibracular & 34.22 & 53.42 & $<0.001$ \\
\hline
\end{tabular}

\section{Avicularian morphometrics and within- colony density among depths}

No depth-related distributional patterns in avicularian morphometric variation were observed. Morphometric data from the 3 depth ranges $(<8,20-300,600-1000$ $\mathrm{m})$ overlapped extensively on the MDS plot forming 1 major cluster (cluster 1) and a smaller disjunct cluster (cluster 2) (Fig.7A). When the same data were categorised according to avicularian type, cluster 1 represented the adventitious, interzooidal and vicarious types, whereas cluster 2 represented the morphometrically distinct vibracular type (Fig. 7B).

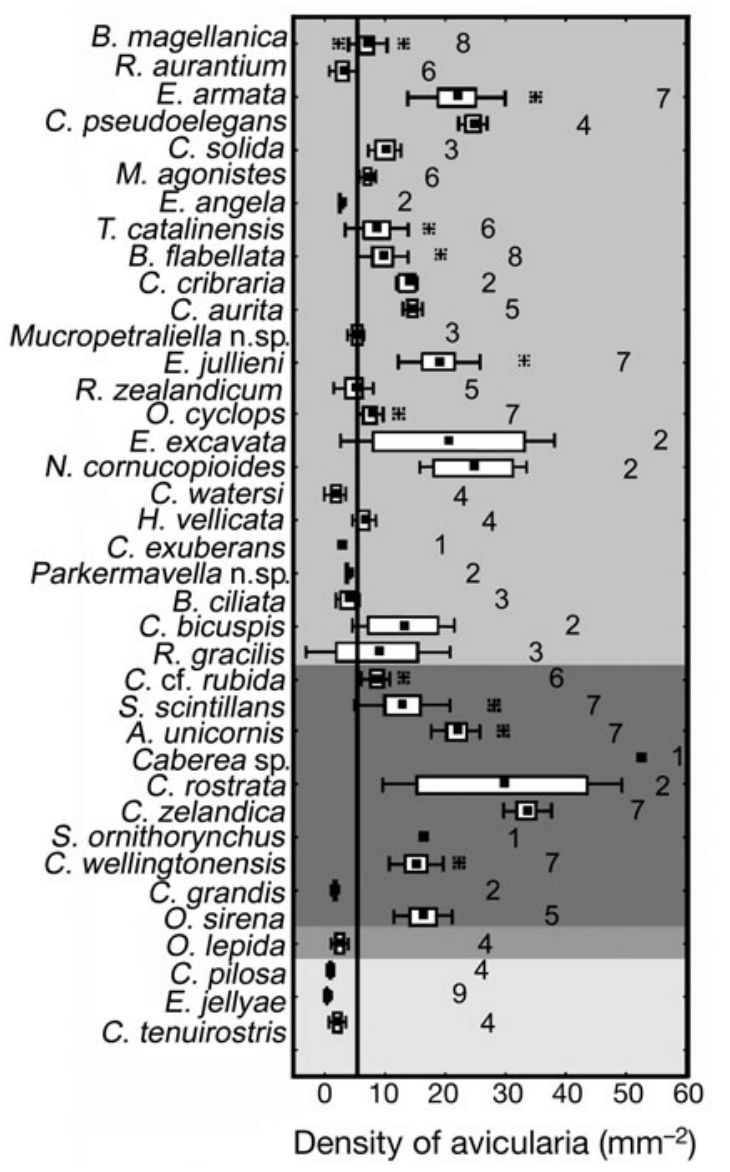

- Mean $\square$ Mean \pm SE I Mean \pm SD $\approx$ Outliers

Fig. 6. Box and whisker plots of density of avicularia $\left(\mathrm{mm}^{-2}\right)$ per colony. Numbers represent number of colony images. Shaded boxes from top to bottom: adventitious only; combined (i.e. adventitious and vibracula, adventitious and vicarious, adventitious and interzooidal); interzooidal only; vicarious only. Solid line represents an arbitrary cut-off point below which all vicarious types are incorporated in order to highlight their low density of avicularia within colonies as well as inter-colony consistency in density. For full species names see Table 1
Density of avicularia showed no distinct depthrelated pattern. Species in deep-sea habitats (600-1000 m) had a similar colony density of avicularia to those species in shallower habitats $(600-1000 \mathrm{~m}$, mean $=13.96 \mathrm{~mm}^{-2}, \mathrm{n}=22$ from 6 species; $<8 \mathrm{~m}$, mean $=11.83 \mathrm{~mm}^{-2}, \mathrm{n}=111$ from 24 species; $20-300 \mathrm{~m}$, mean $=7.0 \mathrm{~mm}^{-2}, \mathrm{n}=13$ from 4 species) (Fig. 8).

\section{DISCUSSION}

Functional diversity among avicularia can be inferred, at least in part, from morphometric disparity among polymorph types both intraspecifically and interspecifically. The specific biological role or roles of any given avicularium will likely be reflected in its functional capacity as defined by mandible morphology, size and shape, musculature, and/or the presence of any sensory structures emerging from the palatal orifice. The presence and arrangement of these sensory structures in some avicularia support diverse functional roles (Carter 2008; M. C. Carter et al. unpubl. data). The present study has revealed extensive morphological diversity among avicularia. Intraspecific variability in avicularian morphometrics can be significant in some species and negligible in others. Adventitious types were the main contributor to morphometric variation in avicularia. The vicarious and vibracula were morphometrically invariable, implying a common functional role among these types. Morphometric consistencies in one type of avicularium within any given species may be due to: (1) selection maintaining an adaptive optimum; (2) developmental constraints, or; (3) mechanical constraints. If morphometric similarity occurs across more than 1 species of a family, this supports the maintenance of an adaptive optimum. In contrast, the morphometric variability in adventitious types was far more complex, and this avicularian type displayed the greatest divergence 

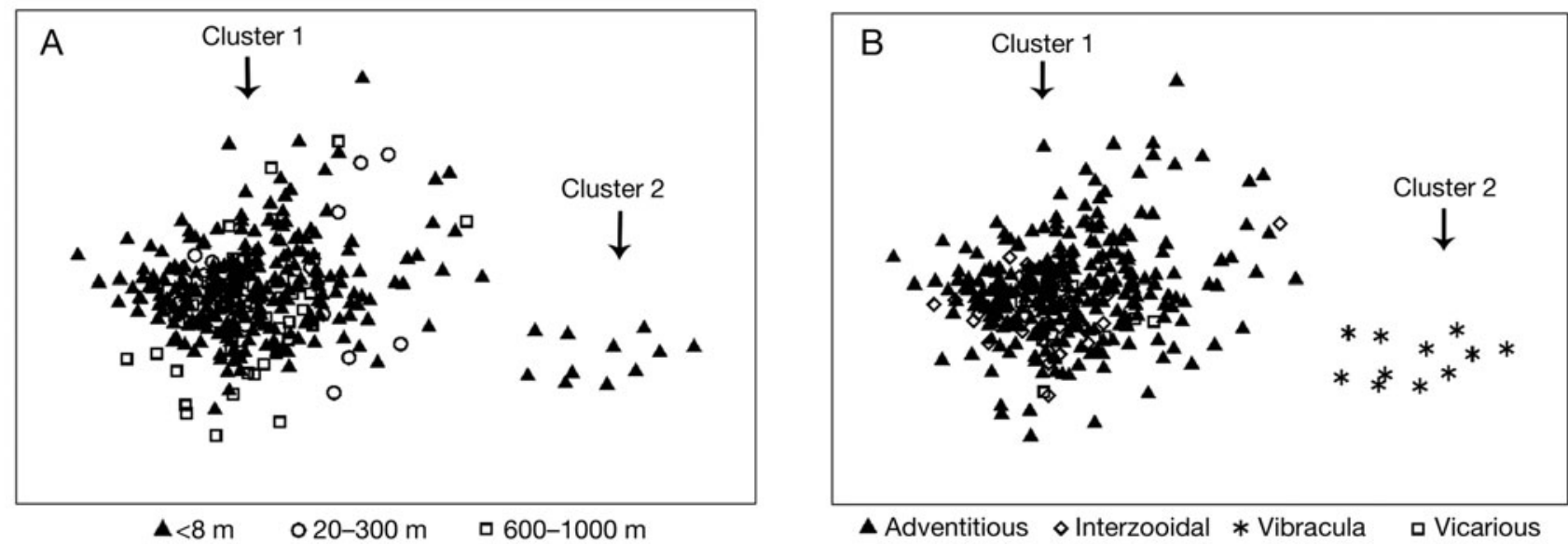

Fig. 7. Non-parametric MDS ordination plots for standardised (s) and $\log _{10}$ transformed avicularian morphometrics (width of avicularia, sWav; length of palate, sLpal; width of palate, sWpal; length of orifice, sLo; width of orifice, sWo) from 34 species and categorised into (A) depth: $<8 \mathrm{~m}, \mathrm{n}=261 ; 20-300 \mathrm{~m}, \mathrm{n}=15 ; 600-1000 \mathrm{~m}, \mathrm{n}=55$, and (B) avicularian type: adventitious ( $\mathrm{n}=269$ ); interzooidal $(\mathrm{n}=28)$; vibracula $(\mathrm{n}=11)$; vicarious $(\mathrm{n}=23)$. Stress level for $(\mathrm{A})$ and $(\mathrm{B})$ : 0.13 . The 2 main clusters are emphasised to illustrate the effect of avicularian type on morphometric variability and not depth. $\mathrm{n}=$ number of avicularia

compared with interzooidal or vicarious types. Where vicarious types were morphometrically similar $(80 \%$ similarity), there was significant morphometric congruence between adventitious, interzooidal and vicarious types. Intraspecifically, adventitious avicularia were either morphometrically constrained (Mucropetraliella n. sp.) or variable (Exochella armata and Reteporella aurantium; the latter has 2 sizes of adventitious avicularia).

Avicularia are assumed to have a defensive function, yet their capacity for such a role and their impact on potential threats to the colony has not been rigorously examined. The morphological diversity of avicularia suggests that many facets of a defensive/protective strategy may have evolved among avicularium-bearing colonies. Defensive mechanisms displayed by sedentary marine invertebrates may be structural or chemical (Dyrynda 1986, Peters et al. 2003, Sharp et al. 2007). Possible defensive mechanisms displayed by avicularia may therefore be of a mechanical (the physical entrapment of organisms) or chemical (secretion of bioactive compounds) nature, or even both. A morphological requirement of an avicularium capable of mechanical defence may include sensory cilia protruding from the orifice in the palate that remain in contact with the external environment when the mandible is open. The bird's-head avicularium of Bugula flabellata (Fig. 1A) meets this criterion, and its mobility is one means by which it may increase encounter rate. For example, the appendage of a passing crustacean may stimulate the exposed cilia, causing the mandible to rapidly close on the appendage (Carter 2008). The high density of the bird's-head avicularia in colonies of B. flabellata $\left(10 \mathrm{~mm}^{-2}\right.$; Fig. 6) enables more than one avicularium to 'capture' a motile invertebrate. In contrast, the hair-like mandibles of vibracula function to remove foreign particles by rotating the toothed mandibles over the colony surface (Cook \& Chimonides 1978, Chimonides \& Cook 1981). Species of Caberea possess 2 types of avicularia: vibracula and small adventitious avicularia. The combination of the 2 functional modules increases intracolony avicularian density and the morphologies of both types support disparate functional roles.

Selection may act independently on constituent zooids of modular organisms, facilitating the development of innovative body plans (Schopf 1973, Hageman 2003, Davidson et al. 2004). Through the hierarchical construction of modular phenotypes, the potential morpho-

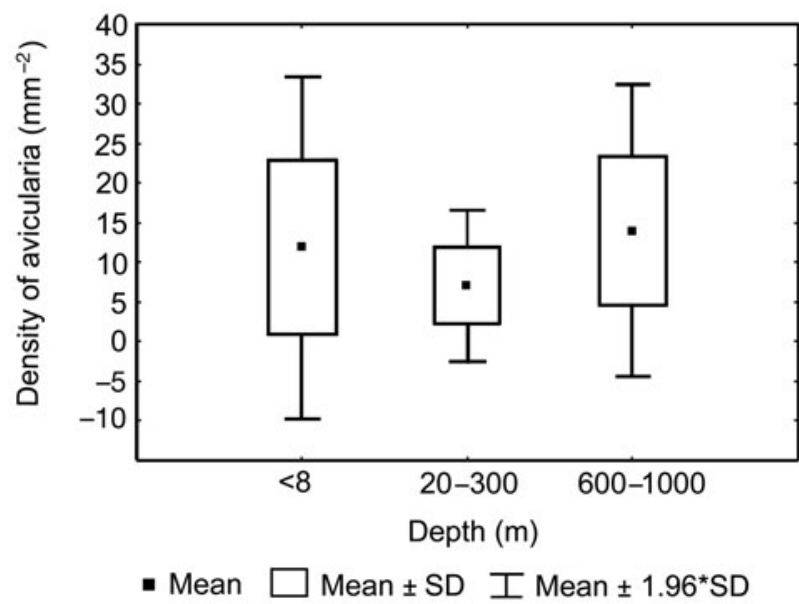

Fig. 8. Box and whisker plots for density of avicularia $\left(\mathrm{mm}^{-2}\right)$ per colony from 34 species: $<8 \mathrm{~m}(\mathrm{n}=111), 20-300 \mathrm{~m}(\mathrm{n}=13)$, $600-1000 \mathrm{~m}(\mathrm{n}=22) . \mathrm{n}=$ number of avicularia 
ecospace that a colony can occupy increases (Hageman 2003). Thus, modular development facilitates plasticity in growth (Hughes 2005) so that cheilostome bryozoans can respond to environmental pressures via the production of a functionally relevant module such as a reproductive zooid, a defensive spine (Harvell 1992, Harvell \& Helling 1993), or an avicularium. The transformation of the zooidal operculum into an avicularian mandible was an important adaptive shift that conferred to the cheilostome Bryozoa the novel capacity to accomplish tasks that are normally associated with limbs, i.e. grasping (the bird's-head avicularium) and flexing/lashing (the seta-bearing vibraculum).

Intraspecific variability in the frequency of occurrence of avicularian modules is known to exist, both at the zooidal and colonial level (Schopf 1973, Winston 1984, Hughes \& Jackson 1990). In Panamanian reef cheilostomes there is significant intraspecific variability in the frequency of occurrence of avicularia in different habitats, implying an environmentally-driven adaptive response (D. J. Hughes unpubl. data cited in Hughes \& Jackson 1990). In our study, no depth-related pattern in colony density existed: species in deep-sea habitats had a similar density to those species in shallow subtidal and intertidal habitats. Additionally, no correlation existed between depth and avicularian morphometrics: the overall contributing factor to the morphometric and colony density pattern was the type of avicularia involved. The morphometric divergence of adventitious avicularia is such that no distinction can be made when compared with the morphometrics of vicarious and interzooidal avicularia (Table 4 ). In this study, $86 \%$ of the 38 species had adventitious avicularia. Of the 47 deep-sea species collected during the Galathea voyage, $9 \%$ had vicarious and $82 \%$ had adventitious avicularia (Hayward 1981). Taxonomic surveys of all known 770 cheilostome species in the New Zealand exclusive economic zone (EEZ) found $5 \%$ with vibracular, $6 \%$ with interzooidal, $5 \%$ with vicarious, $26 \%$ of species having no avicularia and $63 \%$ with adventitious avicularia (Gordon 1984, 1986, 1989, Gordon et al. 2009).

The morphometric diversification and frequency of occurrence of adventitious avicularia suggests an adaptive response with real ecological and evolutionary implications for the division of labour within colonies and colony integration. Integration refers to the degree of connectedness of constituent parts (McShea 2001). The production of one or more adventitious avicularia on the frontal surface of an autozooid potentially increases the abundance of functional modules within a given area of the colony. As our study has highlighted, the density of avicularia is greatest in those colonies with adventitious types only or with adventitious and vibracular types, thereby enhancing integration and specialisation within a smaller spatial scale of the colony. Then the gradual diminishing of spatially and economically demanding types such as vicarious and interzooidal may become apparent over evolutionary time while adventitious types dominate. The ecological and evolutionary implications of such a shift point towards maximising functionality within a smaller spatial scale of the colony in response to pressures from an ecologically relevant cue (e.g. epibiont density, predation) and ultimately enhancing the division of labour within the colony (Schopf 1973).

A recent analysis and survey of bryozoan predators found that generalist consumers such as fishes and decapods can remove significant portions of colonies, whilst species of nudibranchs, pycnogonids, nematodes, small arthropods, turbellarians and some polychaetes are either primarily or exclusively zooid-level predators (Lidgard 2008). As a corollary, it may be ecologically and functionally important for cheilostomes to concentrate the number of defensive mechanisms at the level of the zooid. The degree of avicularian polymorphism is an enigma and is particularly evident in adventitious forms. Avicularia are morphologically equipped to perform many functions which may fit under the generic term of defence. Ultrastructural examination of the vestigial polypide of the adventitious avicularia from 2 members of the family Bugulidae revealed anatomical variances indicative of functional divergence. The vestigial polypide of the bird's-head avicularium of Bugula flabellata comprises externally directed ciliated cells tightly associated with a cerebral ganglion and capable of detecting tactile stimuli from motile epibionts. In contrast, the vestigial polypide of the avicularium of Nordgaardia cornucopioides comprises a large region of glandular cells and internal cilia, possibly to aid the secretion of glandular products (M. C. Carter unpubl. data). The functional roles of these avicularia are independent of phylogenetic relationships. Familial and higher level relationships within the Cheilostomata are poorly understood, and it is not yet possible to reconstruct a phylogenetic tree of the Bugulidae. Habitat differences could well have driven functional divergence: $B$. flabellata is a cosmopolitan inhabitant of ports and harbours, whilst $N$. cornucopioides is a deep-sea seamount inhabitant (Carter 2008).

In conclusion, our analysis has revealed significant morphometric similarity between adventitious, interzooidal and vicarious avicularia, largely as a consequence of extensive divergence in adventitious morphology, whilst vibracular and vicarious types are morphometrically invariable. Adventitious avicularia are more frequently observed in natural populations than are interzooidal, vicarious and vibracular types, and can occur in high colony densities. Our findings indicate that the budding of avicularia adventitiously 
facilitates morphological and functional diversity, and maximises functional capacity by condensing defensive modules within the scale of the progenitor zooid. This redirection in defensive strategy may have real implications for the evolution of defensive mechanisms in subsequent cheilostome lineages, with possibly the production of more elaborate forms. Ecologically, micropredation may be an important evolutionary driving force, and significant advances in avicularian studies should be made with rigorous experimentation to test predatory impacts and the (defensive) roles that the different avicularia may play. This study offers insight into how a modular construction, where constituent modules are committed to different functions, can enhance evolvability (Schlosser \& Wagner 2004). The morphometric variability of adventitious modules has the potential to enhance the evolvability of cheilostome lineages. Modularity pervades every level of biological organisation (Nelson 2004), and this study provides key insight into the implications of such a design.

Acknowledgements. We are grateful to NIWA divers for collecting samples: O. Anderson, M. Francis, S. Mercer, P. Notman, M. Page, A. Smith, R. Stewart and D. Stotter; to D. Flynn (Victoria University of Wellington) and K. Card (Industrial Research Limited) for technical assistance; and to A. Pallentin (NIWA) for providing the maps of NZ. We also thank the 4 anonymous reviewers for their constructive comments which helped improve the manuscript. Bryozoans from the Chatham Rise were collected as part of a research program studying the ecology of seamounts: 'Effects of fishing on underwater topographic features', undertaken by NIWA and funded by the New Zealand Ministry of Fisheries (ENV200516), with additional funding from the New Zealand Foundation for Research, Science, and Technology (contract no. C01X0508), the Centre of Marine Environmental and Economic Research, Victoria University of Wellington and NIWA. M.C. was supported by a Commonwealth PhD Scholarship.

\section{LITERATURE CITED}

Banta WC (1973) Evolution of avicularia in cheilostome Bryozoa. In: Boardman RS, Cheetham AH, Oliver WA (eds) Animal colonies. Dowden, Hutchinson and Ross, Stroudsburg, PA, p 295-303

Carter MC (2008) The functional morphology of avicularia in cheilostome bryozoans. PhD thesis, Victoria University of Wellington, Wellington

Carter MC, Gordon DP, Gardner JPA (2008) A preliminary analysis of avicularian morphology. In: Hageman SJ, Key MM, Winston JE (eds) Bryozoan studies 2007. Spec Publ No. 15. Virginia Museum of Natural History, Martinsville, VA, p 19-30

Cheetham AH (1973) Study of cheilostome polymorphism using principal component analysis. In: Larwood GP (ed) Living and fossil Bryozoa. Academic Press, London, p 385-409

Cheetham AH, Cook PL (1983) General features of the class Gymnolaemata. In: Robison RA (ed) Treatise on invertebrate paleontology, Part G, Bryozoa. Geological Society of
America and University of Kansas Press, Lawrence, p 138-207

Chimonides PJ, Cook PL (1981) Observations on living colonies of Selenaria (Bryozoa, Cheilostomata). II. Cah Biol Mar 22:207-219

Clarke KR, Gorley RN (2006) PRIMER v6: User manual/tutorial. PRIMER-E, Plymouth

Cook PL (1963) Observations on live lunulitiform zoaria of Polyzoa. Cah Biol Mar 4:407-413

Cook PL, Chimonides PJ (1978) Observations on living colonies of Selenaria (Bryozoa, Cheilostomata). I. Cah Biol Mar 19:147-158

Davidson B, Jacobs MW, Swalla BJ (2004) The individual as a module: Solitary-colonial transitions in metazoan evolution and development. In: Schlosser G, Wagner GP (eds) Modularity in development and evolution. The University of Chicago Press, Chicago, p 443-465

Dick MH, Mawatari SF (2005) Morphological and molecular concordance of Rhynchozoon clades (Bryozoa, Cheilostomata) from Alaska. Invertebr Biol 124:344-354

> Dyrynda PEJ (1986) Defensive strategies of modular organisms. Philos Trans R Soc Lond B Biol Sci 313:227-243

> Gardner JPA (2004) A historical perspective of the genus Mytilus (Bivalvia: Mollusca) in New Zealand: multivariate morphometric analyses of fossil midden and contemporary blue mussels. Biol J Linn Soc 82:329-344

Gordon DP (1984) The marine fauna of New Zealand: Bryozoa: Gymnolaemata from the Kermadec Ridge. NZ Oceanogr Inst Mem 91:1-198

Gordon DP (1986) The marine fauna of New Zealand: Bryozoa: Gymnolaemata (Ctenostomata and Cheilostomata Anasca) from the western South Island continental shelf and slope. NZ Oceanogr Inst Mem 95:1-121

Gordon DP (1989) The marine fauna of New Zealand: Bryozoa: Gymnolaemata (Cheilostomida Ascophorina) from the western South Island continental shelf and slope. NZ Oceanogr Inst Mem 95:1-158

Gordon DP, Taylor PD, Bigey FP (2009) Phylum Bryozoa moss animals, sea mats, lace corals. In: Gordon DP (ed) Inventory of New Zealand biodiversity, Vol 1. Kingdom Animalia: Radiata, Lophotrochozoa, Deuterostomia. Canterbury University Press, Canterbury, p 271-297

> Hageman SJ (2003) Complexity generated by iteration of hierarchical modules in Bryozoa. Integr Comp Biol 43: $87-98$

> Harvell CD (1991) Coloniality and inducible polymorphism. Am Nat 138:1-14

> Harvell CD (1992) Inducible defenses and allocation shifts in a marine bryozoan. Ecology 73:1567-1576

> Harvell CD, Helling R (1993) Experimental induction of localized reproduction in a marine bryozoan. Biol Bull 184: 286-295

Harvey PH, Pagel MD (1991) The comparative method in evolutionary biology. Oxford series in ecology and evolution. 1. Oxford University Press, Oxford

Hayward PJ (1981) The Cheilostomata (Bryozoa) of the deep sea. Galathea Rep 15:21-68

Hughes RN (2005) Lessons in modularity: the evolutionary ecology of colonial invertebrates. Sci Mar 69 (Suppl 1): 169-179

Hughes DJ, Jackson JBC (1990) Do constant environments promote complexity of form? The distribution of bryozoan polymorphism as a test of hypotheses. Evolution 44: 889-905

Hyman LH (1959) The invertebrates: smaller coelomate groups Chaetognatha, Hemichordata, Pogonophora, Phoronida, Ectoprocta, Brachiopoda, Sipunculida. The 
coelomate Bilateria. McGraw-Hill Book Company, New York

Jackson JBC (1979) Morphological strategies of sessile animals. In: Larwood GP, Rosen BR (eds) Biology and systematics of colonial organisms. Academic Press, London, p 499-555

Jackson JBC, Cheetham AH (1990) Evolutionary significance of morphospecies: A test with cheilostome Bryozoa. Science 248:579-583

Kaufmann KW (1968) The biological role of Bugula-type avicularia (Bryozoa). In: Annoscia E (ed) Proceedings of the first international conference on Bryozoa. Atti della Società Italiana di Scienze Naturali e del Museo Civico di Storia Naturale di Milano 108, p 54-60

Kaufmann KW (1971) The form and functions of the avicularia of Bugula (Phylum Ectoprocta). Postilla 151:1-26

Lidgard S (2008) Predation on marine bryozoan colonies: taxa, traits and trophic groups. Mar Ecol Prog Ser 359: $117-131$

Marcus LF, Corti M (1996) Overview of the new, or geometric morphometrics. In: Marcus LF, Corti M, Loy A, Naylor GJP, Slice DE (eds) Advances in Morphometrics. Plenum Press, New York, p 1-13

McKinney FK, Jackson JBC (1989) Bryozoan evolution. Unwin Hyman, Boston, MA

McShea DW (2001) Parts and integration: consequences of hierarchy. In: Jackson JBC, Lidgard S, McKinney FK (eds) Evolutionary patterns Growth, form, and tempo in the fossil record. The University of Chicago Press, Chicago, IL, p 27-60

Nelson C (2004) Selector genes and the genetic control of developmental modules. In: Schlosser G, Wagner GP (eds) Modularity in development and evolution. University of Chicago Press, Chicago, IL, p 17-33

Nielsen C (2002) Ciliary filter-feeding structures in adult and larval gymnolaemate bryozoans. Invertebr Biol 121: 255-261

O'Dea A, Herrera-Cubilla A, Fortunato H, Jackson JBC

Editorial responsibility: Roger Hughes,

Bangor, UK
(2004) Life history variation in cupuladriid bryozoans from either side of the Isthmus of Panama. Mar Ecol Prog Ser 280:145-161

Peters L, Gabriele K, Wright A, Pukall R, Stackebrandt E, Eberl L, Riedel K (2003) Secondary metabolites of Flustra folacea and their influence on bacteria. Appl Environ Microbiol 69:3469-3475

Ryland JS (1970) Bryozoans. Hutchinson University Library, London

Sánchez JA, Lasker HR (2003) Patterns of morphological integration in marine modular organisms: supra-module organization in branching octocoral colonies. Proc Biol Sci 270:2039-2044

Schlosser G, Wagner GP (2004) Introduction: The modularity concept in developmental and evolutionary biology. In: Schlosser G, Wagner GP (eds) Modularity in development and evolution. The University of Chicago Press, Chicago, IL, p 1-11

Schopf TJM (1973) Ergonomics of polymorphism: its relation to the colony as the unit of natural selection in species of the phylum Ectoprocta. In: Boardman RS, Cheetham AH, Oliver WA (eds) Animal colonies. Dowden, Hutchinson \& Ross, Stroudsburg, PA, p 247-294

Sharp JH, Winson MK, Porter JS (2007) Bryozoan metabolites: an ecological perspective. Nat Prod Res 24:659-673

Silén L (1977) Polymorphism. In: Woollacott RM, Zimmer RL (eds) Biology of bryozoans. Academic Press, New York, p 184-231

StatSoft Inc (2005) STATISTICA (data analysis software system), version 7.1.www.statsoft.com

Winston JE (1984) Why bryozoans have avicularia-a review of the evidence. Am Mus Novit 2789:1-26

Winston JE (1986) Victims of avicularia. PSZN I: Mar Ecol 7: 193-199

Winston JE (1991) Avicularian behaviour-a progress report. In: Bigey FP (ed) Bryozoa Living and Fossil. Bulletin de la Société des Sciences Naturelles de l'Ouest de la France, Mémoire, HS1, Nantes, p 531-540

Submitted: June 21, 2009; Accepted: September 29, 2009 Proofs received from author(s): January 11, 2010 